Author's version of the article: León-Bravo, V., Caniato, F., \& Caridi, M. (2019). Sustainability in multiple stages of the food supply chain in Italy: practices, performance and reputation. Published in Operations Management Research, 1-22.

https://doi.org/10.1007/s12063-018-0136-9

\title{
Sustainability in multiple stages of the food supply chain in Italy: practices, performance and reputation
}

\begin{abstract}
This study's purposes are threefold. First, to identify the sustainability practices and the motivation behind their implementation across different stages in the chain. Second, to understand the relationship between the sustainability practices in a particular supply chain stage with its operational performances, in the same stage and in other stages. Third, to identify the link between sustainability practices implemented in a particular supply chain stage and reputation in the same stage and in other stages. The study is grounded on the institutional theory and involves multiple cases in four different food supply chain (FSC) stages, in Italy. Findings indicate a varied practice implementation in different stages in the chain, motivated by different institutional pressures, which is in turn related to the company's performance and reputation aims. This multi-stage study provides a more holistic interpretation of sustainability in the FSC, recognizing the importance of setting appropriate sustainability strategies and goals in each stage.
\end{abstract}

Keywords: sustainable supply chain, food industry, sustainability practices, supply chain performance, company reputation

\section{Introduction}

Sustainability from a supply chain perspective in the food industry involves the analysis of companies in different parts of the chain that address scarce natural resources and how their actions directly affect the wellbeing, health and safety of a population, as well as global economic development. Many firms in the food industry observe sustainability from different points of view, e.g., as a competitive advantage, as a corporate responsibility strategy, as an innovative product design, and as a response to consumer expectations about nutrition and health (Beske et al. 2014; Maloni and Brown 2006; Banterle et al. 2013; Kaipia et al. 2013). Nevertheless, companies embarking on such initiatives are usually an exception rather than a standard in the industry (FAO 2014; Gold et al. 2013; Pullman et al. 2009; Beske et al. 2014; Maloni and Brown 2006). Even if the implementation of sustainability awareness and practices in the food supply chain (FSC) is growing, several aspects still need to be considered. 
Author's version of the article: León-Bravo, V., Caniato, F., \& Caridi, M. (2019). Sustainability in multiple stages of the food supply chain in Italy: practices, performance and reputation. Published in Operations Management Research, 1-22.

https://doi.org/10.1007/s12063-018-0136-9

According to previous literature, the type of pressures that a company perceives could explain the reasons motivating sustainability implementation (Sarkis et al. 2011). The coercive, normative and or mimetic pressures (DiMaggio and Powell 1983) could explain the type of practices implemented in different parts of the chain. The coercive pressures refer to the requirements stated by power holders such as governments. The normative pressures indicate the companies' motivations to be perceived as legitimate. And, the mimetic pressures are the motives why companies decide to imitate competitor's behavior (Sarkis et al. 2011).

On the other hand, research considering multiple stages in the supply chain is rather new in the literature (e.g., Mena et al. 2013; Tachizawa and Yew Wong 2014; Touboulic et al. 2014), and in this study, we address the analysis of sustainability practices implementation in more than one or two stages in the supply chain, grounded on the institutional theory. Hence, this study aims to extend the sustainable supply chain management (SSCM) literature, in which limited evidence exists about sustainability practices used at different supply chain stages, and to explore the links between those practices, performance, and reputation, both within the same stage and at the upstream and/or downstream stages, leveraging on institutional theory.

First, regarding performance and sustainability, Pullman et al. (2009) mentions, food industry managers have difficulty measuring benefits from their sustainability initiatives, thus, the link between sustainability practices implementation and performance in different stages of the supply chain needs to be further understood. Research has been seldom carried out about the association of sustainability practices with performance in multiple stages of the supply chain. Companies struggle to capture conflicting strategies and individual actors' performances in the chain because each one has its own mechanisms, processes and criteria (Van Hoek 1998; Aramyan et al. 2007; Kaipia et al. 2013). Consequently, in this study, we intend to understand the link between sustainability and the performance of each stage in the FSC, and in the stages upstream and downstream, both of which are required before an SSCM performance system can be established.

In addition to performance, the link between sustainability practices and company reputation is an important driver for a successful sustainable business strategy (Hoejmose et al. 2014; Roehrich et al. 2014) and has not yet been studied in the supply chain's different stages. When a company is recognized because of its alignment to customer values and cultural beliefs, its reputation or legitimacy may be enhanced (Zott and Huy 2007), as is the case when sustainability is applied. Therefore, sustainability practices are expected to benefit reputation because customers and 
Author's version of the article: León-Bravo, V., Caniato, F., \& Caridi, M. (2019). Sustainability in multiple stages of the food supply chain in Italy: practices, performance and reputation. Published in Operations Management Research, 1-22.

https://doi.org/10.1007/s12063-018-0136-9

stakeholders value responsible behavior; thus, environmental and social practices can develop market confidence, consequently growing the company's reputation (Hoejmose et al. 2014).

Hence, the objectives in the study are first, to identify the sustainability practices applied in different FSC stages according to the institutional pressures perceived. Second, to investigate the relationship between sustainability practices applied in a certain stage and the performance in the same stage and in others. And, third, to understand the relationship between sustainability practices applied with company reputation in the same stage and in others. A set of exploratory cases in four FSC stages are studied in Italy. The findings contribute to extend SSCM literature by contrasting sustainability in four different FSC stages that to date has mainly focused on individual or dyadic scenarios. Grounded on the institutional theory, the study identifies the pressures that shape each FSC stage's approach for sustainability in terms of practice implementation, and their relationship with performance and reputation goals. The study also contributes to literature by identifying the cross-stage relations with performance and reputation. A set of preliminary propositions is formulated as extension of institutional theory highlighting the type of practices related to the performances and reputation pursued by companies in different stages of the chain according to the institutional pressures perceived.

In the following section, we present a comprehensive conceptual background about sustainability within the food supply chain, performance measurement, and the reputation associated with sustainability in the FSC. Thereafter, the research questions and the research framework are presented, and the methodology is described. Finally, the data analysis and findings are discussed, and conclusions are drawn.

\section{Conceptual Background}

\subsection{Sustainability in the food-supply chain}

Sustainability issues are interrelated in the food industry. Several characteristics in this industry as the vast numbers and kinds of products, different shelf-life spans and demanding consumer expectations e.g., food security, availability, quality and price (Fritz and Schiefer 2008; Gold et al. 2013; Maloni and Brown 2006; Beske et al. 2014) are critical factors to consider because they are related to environmental, social and economic impacts. Aramyan et al. (2007) also mentioned that shelf-life constraints, long-production throughput time, seasonality, physical features (i.e., taste, odor, appearance, color, and size), conditioned transportation and storage are conditions affecting 
Author's version of the article: León-Bravo, V., Caniato, F., \& Caridi, M. (2019). Sustainability in multiple stages of the food supply chain in Italy: practices, performance and reputation. Published in Operations Management Research, 1-22.

https://doi.org/10.1007/s12063-018-0136-9

the quantity and quality of food products, and therefore key to be managed and evaluated in order to ensure a quality product and for satisfying consumer demands.

On the other hand, the implementation of practices, programs and/or initiatives for sustainability are expanding in the food industry. Several contributions in the literature identified and categorized groups of practices in different ways. For instance, Maloni and Brown (2006) proposed an eight-dimension framework combining practices from the ethics, purchasing social responsibility and logistics social responsibility literature. Similarly, Beske et al. (2014) presented five categories of practices - strategic orientation, collaboration, continuity, proactivity and risk management - that looked at relationships between SC partners and the flow of goods and information. Likewise, international organizations related to food production, packaging and retail, agriculture and nutrition encouraged actors in the FSC to apply guidelines for sustainability (UN Global Compact 2012; FAO 2014; European Commission 2014; IFOAM 2005; ISEAL 2014).

However, previous studies considered mainly in-house operations, lacking a supply-chain perspective. In the food industry, companies in different stages interact and depend on each other for multiple purposes, in particular, for sustainability. Researchers encourage the examination of larger networks and the observation of differences and requirements along chains (Kaipia et al. 2013; Mena et al. 2013). Therefore, we need to understand how companies act in the different supply-chain stages toward sustainability and how (or if) they assess their resulting performance.

\subsection{Performance in the food-supply chain}

Van der Vorst $(2006,19)$ defines supply-chain performance as "an overall performance measure that depends on the performances of the individual stages and the respective processes that are executed in those stages". Therefore, to improve the entire supply chain's performance, we must look outside individual firms and count performance measurement systems that integrate different performance aspects into a cohesive system (Aramyan et al. 2007; Beamon 1999; van Hoek 1998). Regarding this subject, Beamon (1999) suggests considering efficiency (i.e., "utilization of resources for meeting system's objectives") as the main element to be evaluated. Moreover, the author recommends including responsiveness, quality and customer satisfaction as output measures and, considering flexibility (i.e., "the system's ability to accommodate volume and schedule fluctuations from suppliers, manufacturers and customers"). 
Author's version of the article: León-Bravo, V., Caniato, F., \& Caridi, M. (2019). Sustainability in multiple stages of the food supply chain in Italy: practices, performance and reputation. Published in Operations Management Research, 1-22.

https://doi.org/10.1007/s12063-018-0136-9

Specifically for the FSC, the main contributions focused on analyzing the areas to measure and evaluate performance (van der Vorst 2006; Aramyan et al. 2007; Manzini and Accorsi 2013; Bigliardi and Bottani 2010). For instance, van der Vorst (2006) suggested that measuring performances in FSCs requires a set of financial and non-financial measures, including not only costs, quality and safety but also indicators in the triple bottom line. (i.e., environmental, social and economic dimensions of sustainability (Elkington 1997)). Aramyan et al. (2007) mentioned that quality is a multidimensional performance that takes into account features as taste, color, and texture. Additionally, food quality considers also elements as product safety, sensory properties and shelf life, product reliability. Regarding efficiency in food chains, the authors include elements as production and distribution costs, profits, inventory, and return on investments. Flexibility refers to customer satisfaction, volume and delivery flexibility, backorders management, lost sales. Similarly, Manzini and Accorsi (2012) propose an assessment framework for FSCs considering quality, safety, sustainability and efficiency. The authors highlight that assessment should take into account products, processes and the entire FSC system. On the other hand, Bigliardi and Bottani (2010) developed a balance scorecard model for FSCs including four perspectives: financial, customer, learning and growth, and internal processes. For the aims of our study, we adopt the work proposed by Aramyan et al. (2007) because it offers a framework for measuring performance in the FSC by grouping indicators into the four categories mentioned by Beamon (1999): efficiency, flexibility, responsiveness, and quality. Bourlakis et al. (2014) previously applied this framework where the authors assess the importance of the indicators -four categories mentioned by Aramyan et al. (2007)-, in the sustainability performance of the Greek dairy industry. Furthermore, a more recent contribution by Croom et al. (2018) studied the impact of sustainability practices on operational performances, found how different types of social sustainability practices improved such performances and company reputation as well.

Although previous research addressed the issue of sustainability in supply chains and the effects on different performance dimensions, there is still a lack of investigation regarding the approaches deployed by different supply chain stages that helps to understand how sustainability could be better diffused along the chain and accordingly to achieve better joint performances. 
Author's version of the article: León-Bravo, V., Caniato, F., \& Caridi, M. (2019). Sustainability in multiple stages of the food supply chain in Italy: practices, performance and reputation. Published in Operations Management Research, 1-22.

\subsection{Sustainability and company reputation}

A number of industries, food among them, are exposed to high reputational risk. Food is a highly regulated environment, leading companies to engage in SSCM (Roehrich et al. 2014) given that their operations concern community and employee well-being, resource utilization and economic development.

Company reputation refers to the perceptions and evaluations "developed by stakeholders that favor the company against its competitors" (Czinkota et al. 2014) or to the "aggregate perceptual representation of a company's past actions and future prospects compared against some standard" (Walker 2010). Reputation is built when a company is perceived by stakeholders as different from its competitors because of specific features of the product/service offered (Wolf 2014). For example, when companies implement practices that represent customer's normative values and cultural beliefs (e.g., public health and safety or animal welfare), the market is willing to legitimize companies that appear trustworthy and that have good character (Zott and Huy 2007).

Studies demonstrate the positive relationship between the implementation of environmental and social practices in the supply chain and corporate legitimacy and reputation (Czinkota et al. 2014; Wolf 2014; Roehrich et al. 2014; Hoejmose et al. 2014; Croom et al. 2018). For instance, Wolf (2014) found in her study that companies can build a reputation of 'good citizen' and thus the reduction of risk from reputational damage when implementing sustainability. Roehrich et al. (2014) also studied the exposure to reputational risk and how SSCM can be key for reducing such risks. Similarly, Hoejmose et al. (2014) found evidence that companies in different industrial sectors engage in responsible supply chain management, i.e., addressing social and environmental issues, mainly for protecting and also for enhancing their reputation. Instead, Croom et al. (2018) focused on social sustainability practices - basic and advanced- that help to improve not only company reputation but operational performances as well. Therefore, previous research has observed how companies can apply strategies to acquire legitimacy-including conformance, selection, manipulation and creation (Zimmerman and Zeitz 2002) —with the aims of seizing opportunities or avoiding threats (Keneddy and Fiss 2009). Indeed, sustainability practices can help establish trust and develop company reputation and legitimacy, as seen in many companies that invest in sustainability-oriented practices, highlighting their customers' perceptions of them as good citizens and thereby contributing to their competitive advantage (Wolf 2014). 
Author's version of the article: León-Bravo, V., Caniato, F., \& Caridi, M. (2019). Sustainability in multiple stages of the food supply chain in Italy: practices, performance and reputation. Published in Operations Management Research, 1-22.

https://doi.org/10.1007/s12063-018-0136-9

However, a wider view of sustainability and its association with company reputation in different stages of the supply chain is lacking. The search for protecting or enhancing reputation by the application of sustainability practices (Hoejmose et al. 2014) responds to each company's objectives. Thus, we must understand how companies in SC stages act in this regard; which practices, performances and reputations are common; and which ones differ to identify the conjunction areas that help achieve sustainability along the supply chain.

\section{Research Design}

Contributions in the literature and in practice provide propositions of numerous sustainability practices that companies can apply and indicators to measure the corresponding performance. However, the triple bottom line, has not always been observed simultaneously in past contributions. Often, authors have identified and proposed environmental practices and metrics, but the economic dimension of sustainability has been prioritized when analyzing performance related to sustainability. However, lately, sustainability's social dimension is considered for practices and measures too.

Together with the number of practices and measures already proposed, industry-specific characteristics challenge the practicality of past theoretical propositions for actors in different supply-chain stages. In industries dealing with high product variety and volume, such as the food industry, the scope of a sustainability application is likely to differ across supply-chain stages. Certain features as the number and type of products with which companies deal and the company's core business, size or position in the chain could determine each firm's interest for sustainability. However, as far as our knowledge, these features still need to be studied from a sustainability and supply chain perspective. Additionally, companies might find it unsuitable to apply or adhere to certain frameworks proposed in the literature when they do not see them as appropriate. Similarly, schemes proposed by the industry tend to be complicated for certain types of companies that do not have the resources to apply them or that feel those schemes do not concern them. Thus, it becomes critical to understand how (or if) companies in supply-chain stages address sustainability in terms of implemented practices and the performances they expect to improve, including how company reputation is expected to be protected by sustainability. This characterization would allow for more appropriate systems' propositions for sustainability along the supply chain. 
Author's version of the article: León-Bravo, V., Caniato, F., \& Caridi, M. (2019). Sustainability in multiple stages of the food supply chain in Italy: practices, performance and reputation. Published in Operations Management Research, 1-22.

https://doi.org/10.1007/s12063-018-0136-9

The food industry has evolved to deal with actors spread worldwide, limited resources, and international policies, which enhance its challenges, risks and opportunities (FAO 2014). The FSC is composed of highly varied and heterogeneous types of companies in terms of size, geographical location and product variety (shelf lives, characteristics, quality expectations and packaging requirements). The industry's inherent complexity could imply that diverse business strategies and sustainability initiatives exist; thus, sustainability implementation is expected to be diverse among companies in the same industry.

In this line, this study aims to characterize the complexity of diverse sustainability implementation in the FSC and the correspondingly varied performance and reputation expectations across stages of the FSC. This study intends to evidence the need for ad hoc frameworks that help companies better address their sustainability efforts according to their own performance expectations, including company reputation, and the potential effects these efforts have on their supply chains both upstream and downstream.

\subsection{Research questions and framework}

This study is grounded on the institutional theory (DiMaggio and Powell 1983) which will be the base for analyzing the data and interpreting the results. As explained in previous studies, the regulatory, normative and-or mimetic pressures (DiMaggio and Powell 1983) could drive the application of certain strategies, and in the case of sustainability in the supply chain, this pressures could guide the sustainability implementation (Sarkis et al. 2011) in different stages in the chain. Moreover, authors have pointed out that institutional theory could explain the behavior of companies conforming to certain societal beliefs to acquire legitimacy as reputation enhancement (Zott and Huy 2007; Kennedy and Fiss 2009; Zimmerman and Zeitz 2002). Therefore, the relation between sustainability practices and performance and company reputation can be analyzed through this theoretical lens. The study started with the review of prior studies to develop the set of research questions and a conceptual framework that explains the variables to be studied and the relationships among them (Roehrich et al. 2014; Voss et al. 2002).

Accordingly, the objectives are as follows: (1) to identify and compare sustainability practices implemented in different stages of the food supply chain, (2) to characterize the performances expected in each FSC stage because of the sustainability practices implemented, and (3) to describe how sustainability practices are associated with the protection and/or improvement of a company's 
Author's version of the article: León-Bravo, V., Caniato, F., \& Caridi, M. (2019). Sustainability in multiple stages of the food supply chain in Italy: practices, performance and reputation. Published in Operations Management Research, 1-22.

https://doi.org/10.1007/s12063-018-0136-9

sustainability reputation. To achieve these goals, this study seeks to answer the following research questions:

1. What kind of sustainability practices do different FSC stages implement, according to the institutional pressures perceived?

2. How do operational performances relate to the sustainability practices implemented in different FSC stages, according to the institutional pressures perceived?

2.1. In the same FSC stage?

2.2. To other FSC stages?

3. How does the company sustainability reputation relate to the sustainability practices implemented in different FSC stages, according to the institutional pressures perceived?

3.1. In the same FSC stage?

3.2. To other FSC stages?

Figure 1 schematizes the research framework proposed, identifying the main variables and the relationships among them. The research questions are answered for each of the FSC stages (RQ1, RQ2.1, RQ 3.1), and cross-stage links are considered (RQ 2.2, RQ 3.2). The four FSC stages studied are grower/breeder, processor, distributor and retail, being the main value-adding operations in this supply chain (van der Vorst 2006). Data are collected from different type of companies belonging to different supply-chain stages. The variables to consider in each research question are detailed in the following sections.

\section{-----Fig 1 ABOUT HERE-----}

\subsubsection{Research Question 1:}

For addressing research question 1, the sustainability practices that can be applied in different supply chain stages by companies in food industry need to be operationalized. This investigation characterizes the sustainability practices adopted in each FSC stage, i.e., sustainability-oriented activities, programs or initiatives already implemented. The sustainability practices that will be considered in this study are classified into seven dimensions according to the sustainability triple bottom line (Elkington 1997), as listed in Table 1 (León-Bravo et al. 2017). The practices are derived from Maloni and Brown's (2006) framework, which compiles a list of practices from the 
Author's version of the article: León-Bravo, V., Caniato, F., \& Caridi, M. (2019). Sustainability in multiple stages of the food supply chain in Italy: practices, performance and reputation. Published in Operations Management Research, 1-22.

https://doi.org/10.1007/s12063-018-0136-9

literature and industry trends. Then, the list is adapted and complemented with elements from additional academic and industrial sources (Pullman et al. 2009; Beske et al. 2014; Banterle et al. 2013; UN Global Compact 2012; FAO 2014; European Commission 2014; IFOAM 2005; ISEAL 2014).

\section{-----Table 1 ABOUT HERE-----}

Consequently, Table 1 contemplates sustainability topics in the food industry involving qualitative and intangible factors that are considered important among consumer preferences and for regulatory purposes. Hence, practices can be either voluntary or mandatory. Moreover, the practices can be applied by FSC actors from growers to retailers.

\subsubsection{Research Question 2:}

As mentioned in Section 2.2, the supply chain performances considered in this study are based on the framework proposed by Aramyan et al. (2007). This framework is selected because it includes financial and non-financial indicators for measuring performance, specifically in the agri-food supply chain as also suggested by Bigliardi and Bottani (2010). The framework has been previously applied in sustainability-related studies, such as Bourlakis et al. (2014), and in the food industry.

Table 2 presents the four operational performance categories (i.e., efficiency, flexibility, responsiveness and quality) and the relevant measurement items in each one.

\section{-----Table 2 ABOUT HERE-----}

In this study, we aim to identify the performances currently measured in companies, by formal or informal mechanisms that are related to the sustainability practices implemented. If no measure is in place, we inquire regarding the performance benefits already perceived, if any. For research question 2.1, the analysis is performed per supply chain stage, and for research question 2.2 , the aim is to look at the sustainability practices applied in a stage and their links with performances in other stages, if any. 
Author's version of the article: León-Bravo, V., Caniato, F., \& Caridi, M. (2019). Sustainability in multiple stages of the food supply chain in Italy: practices, performance and reputation. Published in Operations Management Research, 1-22.

https://doi.org/10.1007/s12063-018-0136-9

\subsubsection{Research Question 3:}

This study considers the propositions made by Wolf (2014), Czinkota et al. (2014), Roerich et al. (2014) and Hoejmose et al. (2014), who argue that company reputation is protected or enhanced by the implementation of sustainability practices, i.e., environmental or social. The authors claim that companies apply SSCM first to safeguard their reputations from negative attention when they comply with internal and external regulations and to enhance corporate reputations to secure business contracts and to access new market segments. This argument is in line with Zott and Huy (2007), who explained how organizations take actions to appear trustworthy or decent, build forms of legitimacy and ultimately access to new businesses or resources.

For this study, the elements observed as measures of company reputation represent the ways companies can explain their good status toward the stakeholders. Previous contributions in literature mention elements such as getting positive feedback from stakeholders, competitive advantages (Wolf 2014), employees being prouder of their workplace, staff retention (Hoejmose et al. 2014), reduce or eliminate sustainability issues and controversies (Czinkota et al. 2014). We integrate these elements for company reputation into two different dimensions, environmental and social. Internal and external social reputations are considered separately (See Table 3). As mentioned by Hoejmose et al. (2014), the implementation of SSCM practices can have internal advantages such as staff retention and improved workplace, with practices related to in-house operations and employee well-being, while other practices are applied for enhancing reputation toward external stakeholders and consumers. Hence, we consider environmental and social reputation separately to be able to better relate the sustainability practices with the corresponding sustainability reputation. For research question 3.1, we look at the relation between sustainability practices and company reputation in each FSC stage and for research question 3.2, the aim is to observe how the sustainability practices applied in a stage are associated with the sustainability reputation in other supply-chain stages, if such relationship exists.

\section{-----Table 3 ABOUT HERE-----}

\section{Research Methodology}

This exploratory investigation is based on multiple cases, which according to Yin (2008) "are rich, empirical descriptions of particular instances of a phenomenon that are typically based on a variety 
Author's version of the article: León-Bravo, V., Caniato, F., \& Caridi, M. (2019). Sustainability in multiple stages of the food supply chain in Italy: practices, performance and reputation. Published in Operations Management Research, 1-22.

https://doi.org/10.1007/s12063-018-0136-9

of data sources". The case study methodology is chosen in this study with the aim to explore the phenomenon by recognizing patterns of relationships among constructs within and across cases (Eisenhardt and Graebner 2007; Voss et al. 2002). Case study is considered the appropriate methodology in this work for identifying the relationships of the variables among cases in the same FSC stages and across stages in the chain. Consequently, as several authors suggest, the research includes multiple case studies for answering questions where key variables, patterns and relationships are to be identified (Eisenhardt and Graebner 2007; Yin 2008).

\subsection{Case selection}

For selecting the cases, some research boundaries are established, as suggested by Sarkis (2012). First, the unit of analysis is defined as the company with activities in a specific FSC stage. When a company has activities in more than one stage, that company represents more than one case. Considering the proximity boundary, this study's interest is on FSCs with one or more focal companies in Italy to analyze scenarios with common geographic characteristics. Observing the informational boundary, concepts are defined and explained during the interview to ensure the interviewees are using the same terminology. Additionally, the focus is on the sustainability practices already implemented, the performance currently assessed by formal or informal mechanisms, or the performance recognized even if not actually measured. Similarly, reputation is that which is already recognized as related to the practices implemented. Therefore, the temporal boundary is set to a retrospective analysis.

Subsequently, the cases for this study are chosen following several authors' suggestions to include cases that complement each other in terms of similar contexts, e.g., cases in the same industry and the same supply-chain stage; and cases with a polar-type sampling approach, e.g., small and large companies (Eisenhardt and Graebner 2007; Voss et al. 2002). Hence, the cases in this investigation involve different type of companies working in four different FSC stages, companies of varied sizes (in terms of annual sales) and companies working with different product types. The variety of cases selected intends to grasp the effects of the different institutional pressures on the industry's existing heterogeneity in Italy. Therefore, cases selected in this study not only are expected to represent a wider population of companies in food industry in Italy, but also to achieve replication when analyzing the application of sustainability practices and their relationship with performances and reputation. That is, certain behaviors in terms of practices 
Author's version of the article: León-Bravo, V., Caniato, F., \& Caridi, M. (2019). Sustainability in multiple stages of the food supply chain in Italy: practices, performance and reputation. Published in Operations Management Research, 1-22.

https://doi.org/10.1007/s12063-018-0136-9

implemented could be anticipated per FSC stage (literal replication) and contrasting actions across stages (theoretical replication) (Yin 2008; Caniato et al. 2017).

Accordingly, cases for this study are selected conveniently from four different FSC stages, representing the main value-adding stages in the chain (van der Vorst 2006). Companies work with different type of products, e.g., fresh, processed and conserved; animal or vegetal origin, companies sell their product with their own or private label, are working in a single supply chain stage or are integrated with other stages. As mentioned above, the variety of cases is appropriate in this study for answering the research questions proposed because they would allow to explain the effect of different institutional pressures on the implementation of sustainability practices, if they are either shared or contrasting within stages and across stages, as well as their links with performances and reputation.

Table 4 shows the cases' main characteristics, and Figure 2 represents the case's distribution along the FSC stages. The sample, per stage, is composed of five Grower/Breeders, ten Processors, three Distributors/Transporters, and three Retailers. As mentioned previously, one company can represent more than one case when its activities correspond to more than one stage; for instance, cases $\mathrm{G}$ and $\mathrm{H}$ belong to the same company. Thus, fifteen companies provided twenty-one cases. The number of cases per stage responds to the level of for saturation, that is, when no incremental improvement was achieved (Eisenhardt 1989) or when no new or contrasting information was found in the same FSC stage and across stages.

-----Table 4 ABOUT HERE-----

-----Fig 2 ABOUT HERE-----

\subsection{Data collection and analysis}

Data were collected using semi-structured interviews involving the sustainability and/or supply chain manager in each company and/or the CEO (or delegate). In four companies, we had two respondents during the interview. We conducted fifteen interviews lasting between 60 and 90 minutes each, and in case of clarification requests, respondents were contacted by e-mail. The interview protocol was designed in advance by three researchers and validated by two additional researchers. As interviews proceeded, the protocol was updated and revised in several rounds 
Author's version of the article: León-Bravo, V., Caniato, F., \& Caridi, M. (2019). Sustainability in multiple stages of the food supply chain in Italy: practices, performance and reputation. Published in Operations Management Research, 1-22.

https://doi.org/10.1007/s12063-018-0136-9

according to the new information found and, according to the FSC stage (See Appendix A). The semi-structured interview protocol is appropriate in this study as it allows grasping different features characterizing each case (Pagell and Wu 2009) per supply chain stage and across stages; to include new information found and-or update it (Yin 2008). To ensure validity and reliability (Yin 2008; Voss et al. 2002), the data collected in the interviews (i.e., history, company values, sustainability reports, and certifications) were triangulated with secondary sources such as web information, official reports, archives, magazine articles, and information from supply chain partners, when available. In this manner, a case study database was created.

The data collected were transcribed, coded and organized per case, and per stage, keeping a chain of evidence. The analysis was performed in three steps, first, within case to identify the variables under study per case. Subsequently, a cross-case analysis was performed, i.e., an aggregated listing per FSC stage and a cross-pattern identification analysis to find common behaviors within each stage. Lastly, the cross-stage analysis implied the variables comparison across stages. Hence, in the within analysis first, data was coded according to the practices identified in Table 1. Following, the performances in Table 2 and reputation in Table 3 were related to the practices declared, building on the interviewees' responses and-or based on secondary sources of information, when available. Next, the list of practices implemented per case was categorized according to the institutional pressure driving the implementation of such practice. Ensuing, the cross-case analysis implied to aggregate the information per stage in order to find commonalities or differences, and the potential institutional pressures that motivate each stage to adopt certain practice, and, aim for improvement of certain performance or reputation. Lastly, the cross-stage analysis allowed for a wider supply chain view, intending to recognize patterns and relationship among the constructs under study, if any, along different FSC stages in Italy. The three levels of analysis are grounded on institutional theory as the base for data coding, pattern and relationship recognition among variables. Consequently, the theory will provide a frame for findings' interpretation, and thus, for better understanding the motivations behind sustainability implementation, and, the performances and reputation dimensions attained in different stages of the supply chain. 
Author's version of the article: León-Bravo, V., Caniato, F., \& Caridi, M. (2019). Sustainability in multiple stages of the food supply chain in Italy: practices, performance and reputation. Published in Operations Management Research, 1-22.

https://doi.org/10.1007/s12063-018-0136-9

\section{Findings}

\subsection{Sustainability practices in different stages of the FSC}

Fifty-five different practices were identified during the within case and cross-case analysis. However, in order to facilitate comprehension, we bundled certain practices in groups according to the dimensions proposed in Table 1 and according to the similarities among cases. The final reduced list is presented in Appendix B, which also shows those cases applying each practice. For instance, in the Processor stage, in the Sustainable Sourcing (SS) category, Cases B, C and L implement sustainable procurement practices. In the Distributor stage, in the Green processing, packaging and transportation (GGPT) category, Case Q is the only one implementing waste management practices. The Health and Safety $(H \& S)$ category is the largest category in terms of number of cases implementing these type of practices. This finding is in line with previous research findings in which authors mentioned that the food industry is concerned with product quality and safety (Kaipia et al. 2013; Pullman et al. 2009; Seuring and Muller 2008; Banterle et al. 2013). Nonetheless, Natural Resources Conservation (NRC) and Community-related practices are also importantly present in the sample, showing the industry's interest in these matters, as well.

Examining the sustainability practice implementation per FSC stage, we are able to highlight interesting behaviors. Several practices are specifically implemented in one supply-chain stage or by a single company according to its nature or core business. For example, in Appendix B it is shown that exclusively two Processor companies (B and C) implement most of the practices related to Support SC partners given the direct relation and fair-trade agreements they have with commodity suppliers abroad. In particular, Case B deploys several projects with suppliers in Africa and Latin America to improve their growing and harvesting techniques. Other similarities in the Processor stage are in the adoption of $H \& S$ practices depending on product typology, and freshproduct firms are more concerned with them. This situation takes place in companies that adopt product safety and quality certifications (Cases $\mathrm{H}, \mathrm{J}$, and $\mathrm{N}$ ).

The institutional drivers motivating the adoption of these types of practices could vary. Hence, addressing research question 1 more in detail, the cross-case and cross- stage analyses allowed observing similarities between cases in terms or practices implemented because of institutional pressures. Table 5 summarizes the findings. For instance, the four FSC stages share some common practices in the Health \& Safety policies, i.e., Traceability and HACCP, which in Italy are stated 
Author's version of the article: León-Bravo, V., Caniato, F., \& Caridi, M. (2019). Sustainability in multiple stages of the food supply chain in Italy: practices, performance and reputation. Published in Operations Management Research, 1-22.

https://doi.org/10.1007/s12063-018-0136-9

by law. In line with the previous literature, coercive pressures such as regulations motivate companies to adopt certain behaviors (DiMaggio and Powell 1983; Sarkis et al. 2011).

\section{-----Table 5 ABOUT HERE-----}

Additionally, is observed that a wider range of practices is implemented because of normative pressures for all the four FSC stages. As Sarkis et al. (2011) explained, mimetic or normative pressures (i.e., from the customer or the market) could drive companies to implement environmentally related practices to legitimate their activities. In line with the authors, interviewees in Cases $\mathrm{C}$ and $\mathrm{E}$ mentioned that sustainability practices are often driven by customer expectations (normative) and as a strategy to keep up with the competition or other actors in the industry (mimetic). Table 5 also depicts that practices in the environmental dimension, i.e., NRC and GPPT are implemented because of mimetic pressures.

Looking at behaviors per stage is interesting to notice that the Grower/Breeder is the only stage implementing different $N R C$ practices responding to coercive, normative and mimetic pressures. Knowing that companies in this stage are the smallest in the sample, it is unanticipated to find that they are perceiving all the pressures and striving to deal with all of them. On the other hand, companies in the Processor and Retailer stage seem to be focused on responding to market pressures (normative) when implementing sustainability. For instance, Processor B implementing Support SC partners practices explain how the company invests in infrastructure, technical support and connecting suppliers with financing organizations. These actions might be explained by the company's intention to establish a competitive advantage through their supplier's development and to increase its reputation (or legitimacy) abroad through the development of proper norms and values (Zott and Hut 2007), therefore, responding to normative pressures.

Another observation regarding sustainability practice implementation per stage is in the GPPT category. Three practices (i.e., management of products with short due date, transport optimization and reduction of energy consumption) are implemented in three stages-namely, Processor, Distributor, and Retailer - and not particularly in the Grower/Breeder stage. Indeed, the companies in the upstream stage are not in charge of product transportation. The product with a short due date is consumed in-house; therefore, "no waste is expected" (Cases $\mathrm{O}$ and $\mathrm{R}$ ). These companies do not 
Author's version of the article: León-Bravo, V., Caniato, F., \& Caridi, M. (2019). Sustainability in multiple stages of the food supply chain in Italy: practices, performance and reputation. Published in Operations Management Research, 1-22.

https://doi.org/10.1007/s12063-018-0136-9

use considerable energy in their operations or they use alternative methods; thus, they focus their efforts on animal welfare and soil conservation practices (Cases G, I and $\mathrm{M}$ ) in the $N R C$ category.

In addition, GPPT, Community, $W \& H R$, and $S S$ practices in this stage are implemented by the larger Processors because of their strategic positioning in the market with the objectives of protecting or enhancing their reputations (Wolf 2014; Czinkota et al. 2014; Hoejmose et al. 2014). Additionally, the analysis suggests that mainly larger companies in the Processor stage implement practices in the Sustainable Sourcing and Community categories, whereas smaller firms dedicate their efforts to ensure regulation compliance, i.e., traceability ( $H \& S$ category), and reduce resource consumption (GPPT category).

Still regarding practice implementation per FSC stage, for Distributors, sustainability practices are mainly noticed in the GPPT category, with a focus on logistics operations. Indeed, the core business in these companies is the "safe and efficient transport of food products" (Case K interviewee). Although the practices are not regulated, these companies hope to improve their internal operations with an efficiency objective in mind.

Lastly, in the Retailer stage, practices are mostly implemented in the GPPT and Community categories. The application of these practices depends on the company size, given that larger companies perceive higher pressures from external stakeholders, such as the market and consumer. Therefore, institutional theory explains the normative pressures encouraging retailers to adopt practices to ensure a good impression from the stakeholders (Sarkis et al. 2011; Zott and Huy 2007). As a Case D Interviewee stated, "consumer expectations regarding quality and social involvement within the territory need to be considered and communicated".

\subsection{Performance and reputation influenced by sustainability practices}

\subsubsection{In each stage}

Seeking to answer research questions 2.1 and 3.1, we perform a cross-case analysis by comparing evidence from companies in the same FSC stage. The findings are organized in matrices per FSC stage and per sustainability practice category to explore the commonalities and differences across cases in each stage. Then, a cross-stage analysis is realized by comparing observations among FSC stages and examining the commonalities and differences transversely in the chain. Table 6 summarizes the findings. 
Author's version of the article: León-Bravo, V., Caniato, F., \& Caridi, M. (2019). Sustainability in multiple stages of the food supply chain in Italy: practices, performance and reputation. Published in Operations Management Research, 1-22.

First, we found common performances and reputation perceived in all four FSC stages. Quality and Social Reputation (internal) are linked to social sustainability practices, i.e., $H \& S$ and $W \& H R$, respectively, in all FSC stages. Specifically, the $H \& S$ dimension regulates practices to which all companies must adhere, such as traceability and HACCP norms that in turn influence Quality. These behaviors confirm that the main interest of the food industry is product quality, as Maloni and Brown (2006) and Pullman et al. (2009) explained. Nevertheless, this is not the only FSC concern, as several other objectives and consumer's expectations must be addressed, that is, to respond to normative pressures. An example is the practice in the $W \& R$ dimension; promoting diversity in the workplace is also applied in the four FSC stages, being cases belonging to an integrated company (Cases I, J, and K) and one large retailer, Case D. These companies explain how such a practice promotes a positive company reputation among employees and how their satisfaction, wellbeing and empowerment cause the companies to be considered an attractive work environment and a socially responsible firm.

Other commonalities are found in two or three stages simultaneously in practices implemented to deal with normative pressures. For instance, Community practices are linked to improved Efficiency for Processors and Distributors. In particular, interviewees in Cases J and K and Cases $\mathrm{Q}$ and $\mathrm{U}$ agreed on the positive effect of information sharing with FSC partners. These companies perceived that this kind of collaboration not only helped reduce costs and were thus more efficient but also helped collect information that could be spread to consumers. Observing reputation being influenced by sustainability practices, we found some commonalities among two or three FSC stages as well. Social Reputation is enhanced by the application of Community practices (information sharing, donations, volunteering) in three out of the four stages: Processor, Distributor and Retailer. In this way, companies build a positive image and promote values that can influence consumer decisions (Zott and Huy 2007). Moreover, GPPT practices help improve not only Environmental Reputation for Processors and Retailers, but also Efficiency, as mentioned above. These findings are aligned with the evidence found by Hoejmose et al. (2014) that the implementation of SSCM practices helps to protect or enhance company reputation. Additionally, Processors and Retailers declared that Support to SC partner practices enriched their external Social Reputation. For instance, in addition to case B, the interviewee in Case T mentioned that 
Author's version of the article: León-Bravo, V., Caniato, F., \& Caridi, M. (2019). Sustainability in multiple stages of the food supply chain in Italy: practices, performance and reputation. Published in Operations Management Research, 1-22.

https://doi.org/10.1007/s12063-018-0136-9

results from programs for economic development with the company's suppliers are well perceived by consumers and the community. Furthermore, some stage-specific behaviors are found; e.g., Distributors are the only ones looking to improve Flexibility because of the nature of their activities. Similarly, only Processors explain that their company image is positively spread in the market because of their $S S$ practices to improve their supplier's operations and to keep them close by means of monitoring and controlling. Interviewees (Cases E, H, and J) explained how stakeholders value the care they have for suppliers and how they position their companies as social responsible.

Moreover, as mentioned in the previous section there are practices implemented in order to keep up with competition or with other actors in the industry (mimetic pressures). In this regard, it is observed that GPPT practices are expected to have an effect on Efficiency for Processors, Distributors and Retailers. Practices concerning inbound transportation and waste management in these stages are directly related to operational and waste-related costs; therefore, they are related to companies' efficiencies. For instance, Processors dealing with fresh products (Cases H, J, N, and P) need to strictly maintain the cold chain, and they carefully manage the transportation, as do Distributor U and Retailers D and T. Similarly, all Retailers (cases A, D and T) avoid wasting food that is close to the due date. This approach start being popular in the industry, as the interviewees explained (Case A and D). Similarly, Distributor Q and Processor S also work for reducing waste with the aim of reducing the overall costs. These behaviors confirm Efficiency as the second most important objective for companies in the FSC. Firms aspire to be more organized and to collaborate with other actors in the chain to reduce costs, benchmarking popular practices that are good to achieve their goals. As Bourlakis et al. (2014) also found, companies in the FSC apply sustainability for accomplishing their operational performance objectives. Regarding reputation, Grower/Breeders are the only stage aiming at Environmental Reputation by means of NRC practices implemented as a response to mimetic pressures. For instance, interviewees in Cases $\mathrm{G}$ and $\mathrm{M}$ explained that controlling the use of fertilizers, although not regulatory, and communicating it to the consumer helps them to be noticed as responsible companies.

\subsubsection{In different stages}

The final analysis step was aimed at answering research questions 2.2 and 3.2, that is, to understand how companies link the effects of their sustainability practices to performance and reputation in 
Author's version of the article: León-Bravo, V., Caniato, F., \& Caridi, M. (2019). Sustainability in multiple stages of the food supply chain in Italy: practices, performance and reputation. Published in Operations Management Research, 1-22.

https://doi.org/10.1007/s12063-018-0136-9

other FSC stages according to the institutional pressures perceived, and according to the expectations they have from the stages upstream and downstream. A cross-case analysis among cases per stage and across stages was performed to identify such links, if any. Even if the cases in our study do not belong to the same SC, the consciousness of the effects or expectations from the supply chain partners demonstrate the need to explore the sustainability in the supply chain beyond internal operations and-or dyadic relationships. Figure 3 schematizes the cross-stage association of sustainability practices with performances and reputation in the cases studied. In the figure, the label on the arrow is the arrow-head stage's performance and/or reputation affected by the practices adopted at the arrow-tail stage.

\section{-----Fig 3 ABOUT HERE-----}

The data from the cases revealed the potential links between the practices implemented in each stage and the performances and reputation in the up- or downstream stages. For instance, at the Grower/Breeder's stage, which implemented several $H \& S$ practices (e.g., product certification, traceability) linked to their own Quality, are also linked with improved Quality at the Processor's and Retailer's stage because those practices assure product characteristics along the chain. Companies in the Grower/Breeder stage in our set of cases are integrated with Processors; thus, the $H \& S$ practices related to certifications and regulations are applicable to the entire company. Nonetheless, regarding the link on Retailer's performance, interviewees in Cases G, I and M explain that those certifications are either required or highly appreciated at the Retailer's stage. The certifications represent a product-quality guarantee, allowing Retailers to exhibit it in the shelves. Another example is in the Processor stage, where SS and Support to SC partner practices implemented (e.g., selecting and controlling suppliers or spreading know-how) are FSC stages linked to improved Quality at the Grower's. Case B is an interesting illustration of how actions in one stage aim at developing and improving another stage's performance. Company B invested in production facilities that helped the supplier's associations upgrade their product so it could be sold at better prices. Similarly, GPPT practices implemented by Processors (e.g., reducing packaging) are associated with Efficiency at the Distributor's stage. Interviewees from Cases C and E explain that when they reduced packaging their objective was also to increase transportation volume per 
Author's version of the article: León-Bravo, V., Caniato, F., \& Caridi, M. (2019). Sustainability in multiple stages of the food supply chain in Italy: practices, performance and reputation. Published in Operations Management Research, 1-22.

https://doi.org/10.1007/s12063-018-0136-9

trip performed by Distributors. In this way, Distributors could optimize their loads and reduce the number of trips.

These findings show an intertwined network of effects from sustainability practices on firm performance and reputation, as suggested by Pullman et al. (2009) and Roehrich et al. (2014); the latter authors stated that benefits and costs related to sustainability implementation "do not only impact the focal company but also extend across the supply chain".

\section{Discussion}

The aims in this study are the identification of sustainability practices implemented in different FSC stages and their relationship with operational performances and sustainability reputation. Literature proposes and analyzes the sustainability practices application in food industry (LeónBravo et al. 2017; Maloni and Brown 2006; Beske et al. 2014; Kaipia et al. 2013; Pullman et al. 2009), mainly observing individual company's choices. This study intends to grasp the heterogeneity in this type of industry and to identify the potential differences in sustainability practices application across different stages in the chain that in turn deal with different pressures. Findings summarized in Table 5, Table 6 and Figure 3, suggest different behaviors as response to distinct institutional pressures. The first proposition observes that there is no single common approach to deal with coercive, normative or mimetic pressures for sustainability implementation. Subject to the type of pressure, each FSC stage opts for different combination of practices as exemplified above.

Proposition 1: Sustainability practices implementation will vary according to supply chain stage and the institutional pressures perceived

Proposition 1.1: Coercive pressures, as regulations, require 'Health and safety' practices to be implemented in all stages

Proposition 1.2: Coercive pressures, as regulations, require 'Natural Resources Conservation' practices to be implemented by Grower/ Breeders

Proposition 1.3: Normative pressures, as the aim to be perceived as legitimate, encourage practices implemented in all categories, mainly implemented by Processors 
Author's version of the article: León-Bravo, V., Caniato, F., \& Caridi, M. (2019). Sustainability in multiple stages of the food supply chain in Italy: practices, performance and reputation. Published in Operations Management Research, 1-22.

https://doi.org/10.1007/s12063-018-0136-9

Proposition 1.4: Mimetic pressures, as the imitation or benchmarking or practices, motivate practices in the 'Green processing, packaging and transportation' category by Processors, Distributors and Retailers

Proposition 1.5: Mimetic pressures, as the imitation or benchmarking or practices, motivate practices in the 'Natural Resources Conservation ' category by Grower/ Breeders

In addition, data suggests that two main elements influence the type of practice implemented: company size and working in more than one stage in the FSC (vertical integration). Larger companies are exposed to certain pressures from the market and consumers regarding sustainability; hence, these firms are inclined to deploy more activities and, in some cases, to have a structured sustainability strategy. Instead, integrated companies are able to implement increasingly varied practices as they expand across their operations. Larger and more integrated companies in our study explain that a more extensive practice implementation is motivated by the opportunity to achieve social and economic gains, concurring with the institutional model as applied by Kennedy and Fiss (2009) as well. In this regard, companies also perceive the benefits of their practices in other stages, diffusing the positive effects. On the other hand, smaller, less integrated companies are also implementing several sustainability practices that improve their own performances and are linked to the other stages, but the reasons could be to respond to normative pressures (DiMaggio and Powell 1983; Sarkis et al. 2011) and to avoid social and economic losses (Kennedy and Fiss 2009).

Proposition 2: Sustainability practices implementation is influenced by different factors and will depend on the institutional pressures perceived

Proposition 2.1: Practice implementation is positively influenced by company size

Proposition 2.2: Practice implementation is positively influenced by level of vertical integration

Sustainability practice implementation follows also an operational performance and-or reputation goal. Some practices were common in the four stages and driven by the same type of institutional pressure, to attain the same performance objective. This is the case of regulated $H \& S$ practices for Quality purposes or voluntary $W \& H R$ practices for Social Reputation. However, there are other 
Author's version of the article: León-Bravo, V., Caniato, F., \& Caridi, M. (2019). Sustainability in multiple stages of the food supply chain in Italy: practices, performance and reputation. Published in Operations Management Research, 1-22.

https://doi.org/10.1007/s12063-018-0136-9

type of practices implemented by two or three stages, driven mainly by normative pressures not having the same links with performances or reputation (See Table 6). As exemplified above, the purpose of achieving legitimation and being recognized in the market drives the implementation of a wider variety or practices that in turn are related to different operational performances and reputation. Nonetheless, certain stage-specific behaviors regarding the association between practices and performances and/or reputation are identified. Mainly by two types of pressures drive these behaviors: observing market and consumer expectations (normative and regulations (coercive). This outcome was true for Processors, the only stage attaining Social Reputation by means of Sustainable Sourcing practices, and for Distributors who aimed at improving Flexibility performance with GPPT practices. These findings are also in line with Zott and Huy (2007), who explain that actions are valued according to subjective dimensions like emotions and preferences that make organizations seem credible and legitimate. The commonalities and differences in the cases under study indicate that companies seek to be recognized in the market as environmentally or socially (or both) responsible. The sustainability practices implemented constitute strategies to achieve such legitimacy and enhance company reputations. As Zimmerman and Zeitz (2002) argued, legitimacy is built while "following the rules" or by endorsing and implementing the positive actions, such as sustainability in this study's cases.

Proposition 3: Performances and reputation are related with the sustainability practices implemented according to the FSC stage and will depend on the institutional pressures perceived

Proposition 3.1: Quality performance is positively related with practices implemented due to coercive pressures (regulations), for all stages

Proposition 3.2: Operational performances (Quality, Efficiency, and Flexibility) are positively related with practices implemented due to normative pressures (legitimation), mostly by Processors

Proposition 3.3: Reputation (Environmental and Social) are positively related with practices implemented due to normative pressures (legitimation), mostly by Processors

Proposition 3.4: Operational performances (Quality, Efficiency) are positively related with practices implemented due to mimetic pressures (imitation, benchmarking), for all stages 
Author's version of the article: León-Bravo, V., Caniato, F., \& Caridi, M. (2019). Sustainability in multiple stages of the food supply chain in Italy: practices, performance and reputation. Published in Operations Management Research, 1-22.

https://doi.org/10.1007/s12063-018-0136-9

Proposition 3.5: Reputation (Environmental and Social) are positively related with specific practices implemented by Grower/Breeder and Processors motivated by normative pressures

Sustainability practice implementation in a certain FSC stage is related to performances and reputation for other stages, upstream or downstream. For instance, the GPPT practices applied to the Processors and related to their own Efficiency and Environmental Reputation imply (according to Processors themselves) an increased Efficiency for Distributors and Flexibility and Responsiveness for Retailers. The link to performance and reputation in other stages is observed also from down- to upstream. For example, Retailers implementing $S S$ practices aimed at increasing their own social reputation also have a positive effect on Processor's Efficiency and Grower's Quality and Efficiency. These types of observations show that regarding sustainability, working to improve one's own performance is a valuable aspiration, and positive effects can spread across the chain.

Proposition 4: Positive relationships with performances and reputation are expected upstream and downstream thanks to the practices implemented in a certain supply chain stage.

The set of propositions formulated above, derives from our exploratory work and, certainly, would need to be further tested on a larger scale to be generalized.

\section{Conclusions}

\subsection{Main findings}

There is an increasing interest for sustainability in food industry as it deals scarce natural resources, population wellbeing, health and safety and, global economic development as well. This study extends the investigation to four different stages in the food supply chain by observing the sustainability practice implementation, and, the relationships with operational performances and reputation. The study is grounded on the institutional theory for analyzing the data and interpreting the results.

Regarding practices implementation, each FSC stage applies practices as proposed in the literature (León- Bravo et al. 2017; Maloni and Brown 2006; Beske et al. 2014; Kaipia et al. 2013; 
Author's version of the article: León-Bravo, V., Caniato, F., \& Caridi, M. (2019). Sustainability in multiple stages of the food supply chain in Italy: practices, performance and reputation. Published in Operations Management Research, 1-22.

https://doi.org/10.1007/s12063-018-0136-9

Pullman et al. 2009) but with several differences among the stages. Each stage presents different combinations of practices implemented across the seven categories of sustainability practices proposed, according to the institutional pressures perceived in each stage. All four stages apply some practices in common, while others are specific per stage concurring with the company's objectives. The common practices across the stages are regulated, thus, all actors in the chain are compelled to apply them. According to the institutional theory, these coercive drivers motivate companies to adopt certain sustainability practices (Sarkis et al. 2011). On the other hand, practices in other categories that are specific per stage respond to normative drivers, such as requirements from the market or the consumer, or to be considered responsible and legitimate in the market. Instead, another group of practices is implemented in order to keep up with competitors in the industry.

Findings also suggest that the application of sustainability practices driven by different institutional pressures, are also related to the company's performances and reputation aims. For instance, Quality performance is related to $H \& S$ practices implemented due to coercive pressures for all four FSC stages; however, Grower/Breeders also seek for Quality when they implement $N R C$ practices and respond to normative and mimetic pressures. GPPT practices adopted to respond to normative pressures are related to Efficiency for three FSC stages, and concurrently to Environmental Reputation only for Processors. On the other hand, only voluntary $W \& H R$ practices implemented to as a response to the market and staff expectations (normative pressures) were associated with social reputation for all four stages. In this way, companies develop a better work environment; perceive higher employee commitment and satisfaction, which enhances the company name inside and outside the firm. Community and Support to SC partners' practices are linked to social reputation in three stages of the four studied, depending on each stage's core operations and objectives.

Lastly, this study aimed to identify the association of sustainability practices implemented in one stage with the performance and reputation in other FSC stages (See Figure 3). Cross-stage effects are observed. For instance, from upstream to downstream to ensure food quality along the chain, and operational performances (efficiency, flexibility). From downstream to upstream, to help partners keeping the product features and to encourage better practices up in the chain.

Findings also suggest that company size and vertical integration could be factors that encourage companies in different stages to spread sustainability along the chain. Mainly larger companies 
Author's version of the article: León-Bravo, V., Caniato, F., \& Caridi, M. (2019). Sustainability in multiple stages of the food supply chain in Italy: practices, performance and reputation. Published in Operations Management Research, 1-22.

https://doi.org/10.1007/s12063-018-0136-9

perceive stronger pressures from the market and competitors, therefore, they aim to be legitimate and extend gains along the chain as well. More integrated companies are able to spread the performance and reputation benefits from their sustainability practice implementation.

\subsection{Contribution to research}

In the last decade, the literature has grown regarding the application and performance of sustainability practices in the FSC, mainly focusing on environmental aspects (Banterle et al. 2013). Authors stressed the need to study more than a dyad in the chain and to investigate the effect that sustainability has on performance and on company reputation (Wolf 2014; Beske et al. 2014; Fritz and Schiefer 2008). In this study, we considered four different stages in the FSC, thereby extending the SSCM literature that to date has mainly focused on individual or dyadic examples when studying sustainability practices and effects on performance and/or reputation (Bourlakis et al. 2014, Aramyan et al. 2007; Hoejmose et al. 2014; Czinkota et al. 2014; Roehrich et al. 2014). Recent multi-tier studies (Mena et al. 2013; Touboulic et al. 2014, Tachizawa and Yew Wong 2014) show the importance of studying a wider view of SSCM, and our study expands this literature by contrasting sustainability into four different stages. Hence, identifying and comparing sustainability practices in four supply chain stages provide a wider view of the complexity in this industry for achieving sustainable supply chain management.

Through the lens of institutional theory, our study analyzes the pressures that shape each FSC stage approach for sustainability practices implementation, performance and reputation goals. This study provides evidence to extend what other authors previously explained, including Kennedy and Fiss (2009), who argued that companies implement actions first aiming at achieving economic gains (efficiency performance) and social gains (firm reputation). Our study highlights that companies attain these objectives with sustainability practices implemented for different reasons: to comply with regulations or to adhere to normative pressures (Sarkis et al. 2011). Additionally, our study contributes to SSCM literature regarding implementation of practices showing the differences and commonalities among FSC stages, indicating also that no single list of practices or frameworks is applicable to or appropriate in this industry. Similarly, when observing the link between sustainability practices with performances and reputation in each stage, we see that no unique behavior characterizes the four stages in the FSC, evidencing different ways to achieve certain performance or reputations. 
Author's version of the article: León-Bravo, V., Caniato, F., \& Caridi, M. (2019). Sustainability in multiple stages of the food supply chain in Italy: practices, performance and reputation. Published in Operations Management Research, 1-22.

https://doi.org/10.1007/s12063-018-0136-9

Furthermore, our study opens a wider spectrum when considering four stages together, thereby going a step further than previous studies (Bourlakis et al. 2014, Aramyan et al. 2007; Hoejmose et al. 2014; Czinkota et al. 2014; Roehrich et al. 2014). In this line, our study demonstrates the challenges that companies face when observing sustainability beyond in-house initiatives because diverse behaviors are found in wider networks. For instance, collaborating with other actors might imply benefits but also higher risks. Evaluating one's own performance is already a challenge, and understanding other actors' performance goals and expectations could be more difficult and could also generate important information for the benefit of all actors involved. Hence, our study's findings suggest that generic supply-chain frameworks might not be the most appropriate tool for analyzing multiple supply-chain stages because each stage would have its own needs and objectives, each company would measure its practices differently, and each stage would have different effects on other stages' performances and reputations. Finally, to the best of our knowledge, our analysis is the first that illustrates cross-stage links not only with improved performance but also with sustainability reputation related to the sustainability practices implemented in more than one stage in the supply chain.

Building on the institutional theory, a set of propositions derived from our exploratory work are formulated-The propositions consider the type of pressures that motivate the implementation of sustainability practices in different FSC stages, the factors that influence practice implementation, and, the cross-stage links between practices, performance and reputation along the supply chain.

\subsection{Implications for practitioners}

Based on our findings, the main implications for managers are twofold. First, we help to recognize the different ways of behaving in different FSC stages, thereby paving the way to setting up appropriate goals both upstream and downstream in the chain. Our findings can help establish a synergistic goal-seeking approach across stages. Indeed, if a certain practice is coherent with the goals of the stage implementing it and with the goals of another stage, then the two stages could strengthen collaboration (e.g., share cost/investment) to facilitate the implementation of that practice. This approach could stimulate collaboration along the FSC, even though the specific goal of each stage may be different.

Second, managers should identify which performance category is related to which practices implemented in each stage. Hence, companies would be able to design a differentiated performance 
Author's version of the article: León-Bravo, V., Caniato, F., \& Caridi, M. (2019). Sustainability in multiple stages of the food supply chain in Italy: practices, performance and reputation. Published in Operations Management Research, 1-22.

https://doi.org/10.1007/s12063-018-0136-9

measurement system for each FSC stage, given that the existing general standard frameworks might not be appropriate. This understanding may become crucial when a company is, for example, selecting or evaluating its suppliers because it would not be suitable to ask them to evaluate the same performance parameters that are measured by the buyers.

\subsection{Research limitations}

Nonetheless, the study has several limitations we would like to acknowledge. Given that the study is limited to a single country, considers four specific food supply chain stages and does not include intermediate stages, the results could not be generalized to global food supply chains. In the same line, the cases do not necessarily belong to the same supply chain, which limited the observation of other type of practices that might have been implemented with specific suppliers and or customers. Additionally, the study did not analyze the contingency variables in the cases that could explain the motivations for sustainability implementation. Moreover, tough the study analyzed the relationship between the sustainability practice implementation and operational performances, it did not contemplate the measurement per se.

\subsection{Further research}

Several opportunities for future research arise from this study. For instance, we could consider cases in other geographies or industries and include additional actors in the FSC (e.g., intermediate distribution and transportation) that are relevant in certain product typologies and were not present in our sample. For example, small farmers abroad that cultivate products such as fruits, grains, and tubers might not be able to deliver FSC stages to the processor and are compelled to trade them through a wholesale distributor. Thus, a study in these scenarios would need to include those actors for validating whether the implementation of sustainability practices and performances influenced along the chain still hold.

On the other hand, expanding the study of contingency variables shaping the sustainability behavior in the supply chain could also be important. For instance, analyzing the possible set of causes, e.g., the nature of the business, the company size, and the level of vertical integration that triggers each FSC stage own attitude toward sustainability practices and the objectives pursued/attained. Institutional theory may be helpful for explaining the motivations behind 
Author's version of the article: León-Bravo, V., Caniato, F., \& Caridi, M. (2019). Sustainability in multiple stages of the food supply chain in Italy: practices, performance and reputation. Published in Operations Management Research, 1-22.

https://doi.org/10.1007/s12063-018-0136-9

sustainability practice implementation. Similarly, extending the study to a larger sample for testing the exploratory propositions formulated here.

Additionally, to study sustainability practices performed in collaboration between actors in the FSC and performance effects generated by this kind of relationship. Moreover, in our study, although cases are spread across four stages of the FSC and they do not necessarily belong to the same chain, it would be interesting to observe whether the different behaviors found here still hold for more complete supply chains.

Finally, we should further analyze who in the FSC measures sustainability and how. Therefore, identifying stage behaviors regarding sustainability performance measurements is fundamental for setting appropriate sustainability goals along the chain, which may not be common for everyone; thus, designing an adequate sustainability performance measurement system that is clear, relevant and useful for all actors involved would become possible.

\section{Acknowledgement}

The authors would like to offer their special thanks to Dr. Giuseppe Marzano for his very valuable comments and constructive insights during the data analysis and revision of this manuscript. His willingness to generously give his time has been very much appreciated.

\section{References}

Aramyan LH, Lansink AGO, Van Der Vorst JG, Van Kooten O (2007) Performance measurement in agrifood supply chains: a case study. Supply Chain Management: An International Journal 12(4), 304-315

Banterle A, Cereda E, Fritz M (2013) Labelling and sustainability in food supply networks: A comparison between the German and Italian markets. British Food Journal 115(5), 769-783

Beamon BM (1999) Measuring supply chain performance. International Journal of Operations \& Production Management Vol. 19 No. 3, pp. 275-92

Beske P, Land A, Seuring S (2014) Sustainable supply chain management practices and dynamic capabilities in the food industry: A critical analysis of the literature. International Journal of Production Economics 152, 131-143

Bigliardi, B, Bottani E (2010) Performance measurement in the food supply chain: a balanced scorecard approach. Facilities, 28(5/6), 249-260

Bourlakis M, Maglaras G, Gallear D, Fotopoulos C (2014) Examining sustainability performance in the supply chain: The case of the Greek dairy sector. Industrial Marketing Management 43(1), 56-66

Caniato F, Doran D, Sousa R, Boer H (2017). Designing and developing OM research-from concept to publication. International Journal of Operations \& Production Management 38(9), 1836-1856 
Author's version of the article: León-Bravo, V., Caniato, F., \& Caridi, M. (2019). Sustainability in multiple stages of the food supply chain in Italy: practices, performance and reputation. Published in Operations Management Research, 1-22.

https://doi.org/10.1007/s12063-018-0136-9

Croom S, Vidal N, Spetic W, Marshall D, McCarthy L (2018). Impact of social sustainability orientation and supply chain practices on operational performance. International Journal of Operations \& Production Management 38(12), 2344-2366

Czinkota M, Kaufmann HR, Basile G (2014) The relationship between legitimacy, reputation, sustainability and branding for companies and their supply chains. Industrial Marketing Management 43(1), 91-101

DiMaggio P, Powell W (1983) The Iron Cage Revisited: Institutional Isomorphism and Collective Rationality in Organizational Fields. American Sociological Rev Vol. 48, No. 2, pp. 147-160

Eisenhardt KM, Graebner ME (2007) Theory building from cases: opportunities and challenges. The Academy of Management Journal 50(1), 25-32

Eisenhardt KM (1989) Building theories from case study research. Academy of Management Review $14(4), 532-550$

Elkington J (1997) Cannibals with forks. The triple bottom line of 21st century, Capstone Publishing Ltd. Oxford. 73

EU (European Commission) (2014) Agriculture. A partnership between Europe and farmers. The EU's common agricultural policy (CAP): for our food, for our countryside, for our environment https://publications.europa.eu/en/publication-detail/-/publication/de03ccad-5392-4e10-be978eb92f7cf400/language-en Accessed January 2017

FAO (Food and Agricultural Organization of the United Nations) (2014) The state of food and agriculture 2014. http://www.fao.org/3/a-i4040e.pdf. Accessed January 2017

Fritz M, Schiefer G (2008) Food chain management for sustainable food system development: a European research agenda. Agribusiness, 24: 440-452

Gold S, Hahn R, Seuring S (2013) Sustainable supply chain management in "Base of the Pyramid" food projects - A path to triple bottom line approaches for multinationals? International Business Review 22(5), 784-799

IFOAM- Organics International (2005) Principles of organic agriculture. http://www.ifoam.bio/sites/default/files/poa english_web.pdf. Accessed January 2017

ISEAL alliance (2014) ISEAL Code of good practice. Setting Social and Environmental Standards. Version 6.0 December 2014. https://www.isealalliance.org/sites/default/files/resource/201711/ISEAL_Standard_Setting_Code_v6_Dec_2014.pdf Accessed January 2017

Hoejmose SU, Roehrich JK, Grosvold J (2014) Is doing more doing better? The relationship between responsible supply chain management and corporate reputation. Industrial Marketing Management 43(1), 77-90

Kaipia R, Dukovska-Popovska I, Loikkanen L (2013) Creating sustainable fresh food supply chains through waste reduction. International Journal of Physical Distribution \& Logistics Management 43(3), 262-276

Kennedy MT, Fiss P C (2009) Institutionalization, framing, and diffusion: The logic of TQM adoption and implementation decisions among US hospitals. The Academy of Management Journal 52(5), 897-918.

León-Bravo V, Caniato F, Caridi M, Johnsen T (2017). Collaboration for Sustainability in the Food Supply Chain: A Multi-Stage Study in Italy. Sustainability 9, no. 7: 1253.

Maloni MJ, Brown ME (2006) Corporate social responsibility in the supply chain: an application in the food industry. Journal of Business Ethics, 68(1), 35-52

Manzini R, Accorsi R (2013) The new conceptual framework for food supply chain assessment. Journal of Food Engineering 115(2), 251-263 
Author's version of the article: León-Bravo, V., Caniato, F., \& Caridi, M. (2019). Sustainability in multiple stages of the food supply chain in Italy: practices, performance and reputation. Published in Operations Management Research, 1-22.

https://doi.org/10.1007/s12063-018-0136-9

Mena C, Humphries A, Choi TY (2013) Toward a Theory of Multi-Tier Supply Chain Management. Journal of Supply Chain Management 49(2), 58-77

Pagell M, Wu Z (2009) Building a more complete theory of sustainable supply chain management using case studies of 10 exemplars. Journal of Supply Chain Management 45(2), 37-56

Pullman ME, Maloni MJ, Carter CR (2009) Food for thought: social versus environmental sustainability practices and performance outcomes. Journal of Supply Chain Management 45(4), 38-54

Roehrich, J, Grosvold J, Hoejmose S (2014) Reputational risks and sustainable supply chain management: Decision making under bounded rationality. International Journal of Operations \& Production Management 34 (5), 695-719

Sarkis J (2012) A boundaries and flows perspective of green supply chain management. Supply Chain Management: An International Journal 17(2), 202-216

Sarkis J, Zhu Q, Lai KH (2011) An organizational theoretic review of green supply chain management literature. International Journal of Production Economics 130(1), 1-15.

Tachizawa E, Yew Wong C (2014) Towards a theory of multi-tier sustainable supply chains: A systematic literature review. Supply Chain Management: An International Journal 19(5/6), 643-663

Touboulic A, Chicksand D, Walker H (2014) Managing imbalanced supply chain relationships for sustainability: A power perspective. Decision Sciences 45(4), 577-619

UN (United Nations) Global Compact (2012) Scaling up Global Food Security and Sustainable Agriculture https://www.unglobalcompact.org/docs/issues_doc/agriculture and food/Scaling_Up_Food_Ag.pdf. Accessed January 2017

Van Der Vorst JG (2006) Performance measurement in agri-food supply-chain networks. In Ondersteijn, C.J.M.; Wijnands, J.H.M.; Huirne, R.B.M.; van Kooten, O. (eds) Quantifying the agri-food supply chain, Springer, Netherlands, 15-26

Van Hoek RI (1998) Measuring the unmeasurable-measuring and improving performance in the supply chain. Supply Chain Management: An International Journal 3(4), 187-192. ISSN:1359-8546

Voss C, Tsikriktsis N, Frohlich M (2002) Case research in operations management. International Journal of Operations \& Production Management 22(2), 195-219

Walker K (2010) A systematic review of the corporate reputation literature: Definition, measurement, and theory. Corporate Reputation Review 12(4), 357-387

Wolf J (2014) The relationship between sustainable supply chain management, stakeholder pressure and corporate sustainability performance. Journal of Business Ethics, 119(3), 317-328

Yin RK (2008) Case study research: Design and Methods. Sage Publications, Thousand Oaks, CA. 4th Ed., p. 240

Zimmerman MA, Zeitz GJ (2002) Beyond survival: Achieving new venture growth by building legitimacy. Academy of Management Review 27(3), 414-431

Zott C, Huy QN (2007) How entrepreneurs use symbolic management to acquire resources. Administrative Sciences Quarterly 52(1), 70-105 
Author's version of the article: León-Bravo, V., Caniato, F., \& Caridi, M. (2019). Sustainability in multiple stages of the food supply chain in Italy: practices, performance and reputation. Published in Operations Management Research, 1-22.

https://doi.org/10.1007/s12063-018-0136-9

Table 1 Sustainability practices in the food industry (León-Bravo et al. 2017)

\begin{tabular}{|c|c|c|}
\hline \multicolumn{2}{|c|}{$\begin{array}{l}\text { Sustainability } \\
\text { dimension }\end{array}$} & Example of Practices \\
\hline \multirow{2}{*}{ 若 } & $\begin{array}{l}\text { Natural } \\
\text { Resources } \\
\text { conservation } \\
(\mathrm{NRC})\end{array}$ & $\begin{array}{l}\text { Animal Welfare: Elimination of cruelty, safe handling, housing, } \\
\text { slaughter and transport } \\
\text { Soil conservation: Conservation of forests and species, prevent soil } \\
\text { erosion and pollution, prevent loss of arable land and biodiversity, apply } \\
\text { responsible farming methods (reducing fertilizer and pesticides), } \\
\text { eliminate contaminants and pollutants } \\
\text { Water conservation: reduce water consumption, use water efficiently, } \\
\text { waste water re-use and recovery }\end{array}$ \\
\hline & $\begin{array}{l}\text { Green } \\
\text { processing, } \\
\text { packaging } \\
\text { and } \\
\text { transportation } \\
\text { (GPPT) }\end{array}$ & $\begin{array}{l}\text { Design, materials and packaging: design for reuse and recycling, design } \\
\text { for disassembly and reuse, material reuse and recycle, reduce } \\
\text { packaging, use reusable/recyclable packaging } \\
\text { Waste: reduce waste and hazardous materials, compost organic waste, } \\
\text { produce renewable energy or animal feed with waste, lower disposal } \\
\text { costs, damage compensation, recycle } \\
\text { Processing and transportation: reduce energy use, conserve energy, } \\
\text { reduce CO2 emissions and GHGs, reduce pollution, reduce fuel } \\
\text { consumption }\end{array}$ \\
\hline \multirow{3}{*}{$\begin{array}{l}\overline{\frac{\pi}{8}} \\
0 \\
0\end{array}$} & $\begin{array}{l}\text { Health and } \\
\text { Safety }(H \& S)\end{array}$ & $\begin{array}{l}\text { Improve product quality, food safety, food security, traceability and } \\
\text { transparency; promote healthy life styles and local food sources; find } \\
\text { safer warehousing and transportation }\end{array}$ \\
\hline & $\begin{array}{l}\text { Work and } \\
\text { Human } \\
\text { Rights } \\
\text { (W\&HR) }\end{array}$ & $\begin{array}{l}\text { Better working conditions that result in higher levels of motivation and } \\
\text { productivity and less absenteeism; training, education, advancement; } \\
\text { regular employment, elimination of illegal and child labor, respect of } \\
\text { worker rights, gender equality, freedom of association, safe working } \\
\text { conditions }\end{array}$ \\
\hline & Community & $\begin{array}{l}\text { Donation, collaboration with NGOs, philanthropy, support to the } \\
\text { economic development in local communities, educational practices, } \\
\text { health care, job training, volunteering, childcare }\end{array}$ \\
\hline \multirow{2}{*}{ 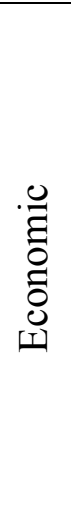 } & $\begin{array}{l}\text { Sustainable } \\
\text { sourcing (SS) }\end{array}$ & $\begin{array}{l}\text { Increasing supplier diversity, confidentiality, eliminating deception and } \\
\text { impropriety, transparency, proper purchasing processes (reciprocity, } \\
\text { fairness, no power abuse or special treatment), minority suppliers, } \\
\text { suppliers' labor programs, local sourcing that result in shorter lead- } \\
\text { times; environmental and social considerations when selecting, } \\
\text { monitoring and controlling suppliers }\end{array}$ \\
\hline & $\begin{array}{l}\text { Support SC } \\
\text { partners }\end{array}$ & $\begin{array}{l}\text { Profit sharing with actors in the upstream SC, premium price payments, } \\
\text { support and monitoring for obtaining sustainability certification; } \\
\text { facilitate partners' access to markets, knowledge and technology } \\
\text { transfer, fostering financing opportunities, information and expertise } \\
\text { sharing }\end{array}$ \\
\hline
\end{tabular}


Author's version of the article: León-Bravo, V., Caniato, F., \& Caridi, M. (2019). Sustainability in multiple stages of the food supply chain in Italy: practices, performance and reputation. Published in Operations Management Research, 1-22. https://doi.org/10.1007/s12063-018-0136-9

Table 2 Performance dimensions in the FSC (adapted from Bourlakis et al. 2014 and Aramyan et al. 2007)

\begin{tabular}{|c|c|}
\hline Performance dimension & Measurement element \\
\hline \multirow{4}{*}{ Efficiency } & Operational costs: production and distribution \\
\hline & Inventory cost \\
\hline & Financial cost: transactions costs \\
\hline & Gross profit margin: return on investments \\
\hline \multirow{4}{*}{ Flexibility } & Delivery flexibility: to extra points of sale, changing volumes \\
\hline & Ability to change output levels \\
\hline & Backorders management \\
\hline & Lost sales \\
\hline \multirow{6}{*}{ Responsiveness } & Fill rate \\
\hline & Delivery to arranged location(s) \\
\hline & Lead time \\
\hline & Product/volume mix-fill rate \\
\hline & Consumer complaints \\
\hline & Shipping errors \\
\hline \multirow{4}{*}{ Quality } & Sensory properties and shelf life \\
\hline & Product safety and health: conservation time \\
\hline & Traceability \\
\hline & $\begin{array}{l}\text { Packaging and labeling: convenience and reliability } \\
\text { Storage and delivery conditions }\end{array}$ \\
\hline
\end{tabular}


Author's version of the article: León-Bravo, V., Caniato, F., \& Caridi, M. (2019). Sustainability in multiple stages of the food supply chain in Italy: practices, performance and reputation. Published in Operations Management Research, 1-22.

https://doi.org/10.1007/s12063-018-0136-9

Table 3 Sustainability reputation elements considered in the study (taken from Wolf 2014;

Czinkota et al. 2014; Hoejmose et al. 2014; Roerich et al. 2014)

\begin{tabular}{|c|c|c|c|}
\hline & \multicolumn{3}{|c|}{ Company's sustainability reputation } \\
\hline & & Social & Environmental \\
\hline & Internal & External & \\
\hline \multirow{15}{*}{ 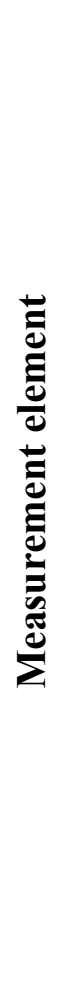 } & Staff retention & Strategic positioning & Strategic positioning \\
\hline & Employee empowerment & Credibility and responsibility & Credibility and responsibility \\
\hline & Employee satisfaction & Consumer loyalty & Consumer loyalty \\
\hline & Employee wellbeing & Competitive advantage & Competitive advantage \\
\hline & Turnover decrease & Positive supplier feedback & Positive supplier's feedback \\
\hline & Employee pride & $\begin{array}{l}\text { Company perception in the } \\
\text { market }\end{array}$ & $\begin{array}{l}\text { Company perception in the } \\
\text { market }\end{array}$ \\
\hline & Company culture & $\begin{array}{l}\text { Customer trust and purchase } \\
\text { intentions }\end{array}$ & $\begin{array}{l}\text { Customer trust and purchase } \\
\text { intentions }\end{array}$ \\
\hline & & Social status & $\begin{array}{l}\text { Credible environment } \\
\text { management }\end{array}$ \\
\hline & & Prevent negative press & Good citizenship \\
\hline & & Fewer consumer complaints & $\begin{array}{l}\text { Differentiation from } \\
\text { competitors }\end{array}$ \\
\hline & & Supplier and investor retention & $\begin{array}{l}\text { Collaborative awareness } \\
\text { building }\end{array}$ \\
\hline & & Consumer engagement & \\
\hline & & Increased bargaining power & \\
\hline & & Goodwill trust of stakeholders & \\
\hline & & Corporate branding & \\
\hline
\end{tabular}


Author's version of the article: León-Bravo, V., Caniato, F., \& Caridi, M. (2019). Sustainability in multiple stages of the food supply chain in Italy: practices, performance and reputation. Published in Operations Management Research, 1-22.

https://doi.org/10.1007/s12063-018-0136-9

\section{Table 4 General description of cases studied}

\begin{tabular}{|c|c|c|c|c|}
\hline Case & Industry Sub-sector & FSC stage & $\begin{array}{l}\text { Sales } 2013 \\
\text { (million } € \text { ) }\end{array}$ & Employees \\
\hline A & Food products retail & Retailer & 63,09 & 757 \\
\hline $\mathrm{B}$ & $\begin{array}{l}\text { Production of chocolate and semi- } \\
\text { finished products for the confectionery } \\
\text { industry }\end{array}$ & Processor & $109,27^{*}$ & 262 \\
\hline $\mathrm{C}$ & $\begin{array}{l}\text { Canned food production based on fish, } \\
\text { meat, seasonings and tuna }\end{array}$ & Processor & 719,11 & 757 \\
\hline $\mathrm{D}$ & Hypermarket retail & Retailer & $2.656,48$ & 9.777 \\
\hline $\mathrm{E}$ & Beer production & Processor & 774,37 & 974 \\
\hline $\mathrm{F}$ & $\begin{array}{l}\text { Semi-finished products made with nuts } \\
\text { for confectionery and ice cream industry }\end{array}$ & Processor & $4,64^{*}$ & 18 \\
\hline $\mathrm{G}$ & Vegetables cultivation & Grower & \multirow[b]{2}{*}{6,95} & \multirow[b]{2}{*}{30} \\
\hline $\mathrm{H}$ & $\begin{array}{l}\text { Fruit and vegetables: processing and } \\
\text { sales }\end{array}$ & Processor & & \\
\hline $\mathrm{I}$ & Vegetables cultivation & Grower & \multirow{3}{*}{$110,52 *$} & \multirow{3}{*}{290} \\
\hline $\mathrm{J}$ & $\begin{array}{l}\text { Fruit and vegetables: processing and } \\
\text { sales }\end{array}$ & Processor & & \\
\hline K & $\begin{array}{l}\text { Distribution of finished products based } \\
\text { on vegetables and fruits }\end{array}$ & Distributor & & \\
\hline $\mathrm{L}$ & Preserved pastry production & Processor & $345,72 *$ & 1.065 \\
\hline $\mathrm{M}$ & Vegetables cultivation & Grower & \multirow[b]{2}{*}{64,26} & \multirow[b]{2}{*}{380} \\
\hline $\mathrm{N}$ & $\begin{array}{l}\text { Fruit and vegetables: processing and } \\
\text { sales }\end{array}$ & Processor & & \\
\hline $\mathrm{O}$ & Livestock breeder & Breeder & \multirow{2}{*}{43,81} & \multirow{2}{*}{125} \\
\hline $\mathrm{P}$ & Dairy production and sales & Processor & & \\
\hline $\mathrm{Q}$ & Beverages wholesaling & Distributor & 428,48 & 1086 \\
\hline $\mathrm{R}$ & Livestock breeder & Breeder & \multirow{2}{*}{$\mathrm{N} / \mathrm{A}$} & \multirow{2}{*}{$\mathrm{N} / \mathrm{A}$} \\
\hline $\mathrm{S}$ & Dairy production and sales & Processor & & \\
\hline $\mathrm{T}$ & Food products retail and catering & Retailer & 130,13 & 733 \\
\hline $\mathrm{U}$ & Merchandise transportation & Distributor & 168,63 & 583 \\
\hline
\end{tabular}


Author's version of the article: León-Bravo, V., Caniato, F., \& Caridi, M. (2019). Sustainability in multiple stages of the food supply chain in Italy: practices, performance and reputation. Published in Operations Management Research, 1-22.

https://doi.org/10.1007/s12063-018-0136-9

Table 5 Institutional pressures motivating sustainability practices in different FSC stages

\begin{tabular}{|c|c|c|c|c|c|c|}
\hline \multirow{2}{*}{\begin{tabular}{|c|}
$\begin{array}{c}\text { Institutional } \\
\text { pressures }\end{array}$ \\
Coercive
\end{tabular}} & \multicolumn{4}{|c|}{ FSC stage } & \multicolumn{2}{|r|}{ Sustainability practices } \\
\hline & $\mathrm{G} / \mathrm{B}$ & & & & NRC & Animal welfare: feed control \\
\hline & $\mathrm{G} / \mathrm{B}$ & $\mathrm{P}$ & $\mathrm{D}$ & $\mathrm{R}$ & $\mathrm{H} \& \mathrm{~S}$ & Ensuring traceability \\
\hline & $\mathrm{G} / \mathrm{B}$ & $\mathrm{P}$ & $\mathrm{D}$ & $\mathrm{R}$ & $\mathrm{H} \& \mathrm{~S}$ & HACCP compliance \\
\hline \multirow[t]{22}{*}{ Normative } & $\mathrm{G} / \mathrm{B}$ & & & & NRC & $\begin{array}{l}\text { Animal welfare: veterinary checkups, } \\
\text { sustainable fishing, open areas for livestock }\end{array}$ \\
\hline & $\mathrm{G} / \mathrm{B}$ & & & & NRC & Soil conservation \\
\hline & & $\mathrm{P}$ & & & $\mathrm{NRC}$ & Collaboration with NGOs for NRC \\
\hline & $\mathrm{G} / \mathrm{B}$ & $\mathrm{P}$ & & & $\mathrm{NRC}$ & Reduction in water consumption \\
\hline & & $\mathrm{P}$ & & $\mathrm{R}$ & GPPT & Packaging reduction, redesign, new materials \\
\hline & & $\mathrm{P}$ & $\mathrm{D}$ & & GPPT & $\begin{array}{l}\text { Processing and transportation: reduction in } \\
\text { energy consumption, cleaner technology, } \\
\text { renewable energy, resources use optimization }\end{array}$ \\
\hline & & $\mathrm{P}$ & $\mathrm{D}$ & $\mathrm{R}$ & GPPT & $\begin{array}{l}\text { Waste management: reduction, re-use, sub- } \\
\text { products utilization, due-date control and } \\
\text { handling }\end{array}$ \\
\hline & & $\mathrm{P}$ & $\mathrm{D}$ & $\mathrm{R}$ & GPPT & $\begin{array}{l}\text { Other GPPT practices: Environmental } \\
\text { certification }\end{array}$ \\
\hline & & $\mathrm{P}$ & & $\mathrm{R}$ & Community & Collaboration with NGO's \\
\hline & & $\mathrm{P}$ & $\mathrm{D}$ & & Community & $\begin{array}{l}\text { Information sharing about resources } \\
\text { consumption }\end{array}$ \\
\hline & & $\mathrm{P}$ & & $\mathrm{R}$ & Community & Donations \\
\hline & & $\mathrm{P}$ & & $\mathrm{R}$ & Community & $\begin{array}{l}\text { Volunteering, investments, events for } \\
\text { promoting sustainability, territorial } \\
\text { development }\end{array}$ \\
\hline & & $\mathrm{P}$ & & $\mathrm{R}$ & Community & Consumer education about healthier habits \\
\hline & & $\mathrm{P}$ & & & Community & Products for specific categories of consumers \\
\hline & G/B & $\mathrm{P}$ & & & $\mathrm{H} \& \mathrm{~S}$ & Products quality and safety certifications \\
\hline & $\mathrm{G} / \mathrm{B}$ & $\mathrm{P}$ & $\mathrm{D}$ & $\mathrm{R}$ & W\&HR & $\begin{array}{l}\text { Promoting and guaranteeing diversity in the } \\
\text { work environment }\end{array}$ \\
\hline & & $\mathrm{P}$ & $\mathrm{D}$ & $\mathrm{R}$ & W\&HR & Sustainability training for employees \\
\hline & $\mathrm{G} / \mathrm{B}$ & $\mathrm{P}$ & $\mathrm{D}$ & & W\&HR & Standards or programs for employees safety \\
\hline & $\mathrm{G} / \mathrm{B}$ & $\mathrm{P}$ & & $\mathrm{R}$ & SS & $\begin{array}{l}\text { Selection, monitoring and control } \\
\text { partners/suppliers considering environmental } \\
\text { and social factors }\end{array}$ \\
\hline & & $\mathrm{P}$ & & & SS & \begin{tabular}{|l} 
Sustainable procurement practices \\
\end{tabular} \\
\hline & & $\mathrm{P}$ & & & $\begin{array}{l}\text { Support SC } \\
\text { partners }\end{array}$ & Facilitate and/or spread know-how \\
\hline & & $\mathrm{P}$ & & $\mathrm{R}$ & $\begin{array}{l}\text { Support SC } \\
\text { partners }\end{array}$ & $\begin{array}{l}\text { Investment/ fostering financial assistance / } \\
\text { joint strategies for economic development }\end{array}$ \\
\hline \multirow[t]{2}{*}{ Mimetic } & G/B & & & & NRC & $\begin{array}{l}\text { Soil conservation: organic production, } \\
\text { fertilizer reduction }\end{array}$ \\
\hline & & $\mathrm{P}$ & & $\mathrm{R}$ & GPPT & Packaging reduction, use of new materials \\
\hline
\end{tabular}


Author's version of the article: León-Bravo, V., Caniato, F., \& Caridi, M. (2019). Sustainability in multiple stages of the food supply chain in Italy: practices, performance and reputation. Published in Operations Management Research, 1-22. https://doi.org/10.1007/s12063-018-0136-9

\begin{tabular}{|c|c|c|c|c|c|c|}
\hline & & & D & & GPPT & $\begin{array}{l}\text { Processing and transportation: cleaner } \\
\text { technology (fleet renewal) }\end{array}$ \\
\hline & & $\mathrm{P}$ & & $\mathrm{R}$ & GPPT & $\begin{array}{l}\text { Other GPPT practices: Environmental } \\
\text { certification, LCA projects }\end{array}$ \\
\hline
\end{tabular}


Author's version of the article: León-Bravo, V., Caniato, F., \& Caridi, M. (2019). Sustainability in multiple stages of the food supply chain in Italy: practices, performance and reputation. Published in Operations Management Research, 1-22.

https://doi.org/10.1007/s12063-018-0136-9

Table 6 Performance and reputation associated with sustainability practices according to the institutional pressures perceived. (G/B: Grower/ Breeder, P: Processor, D: Distributor, and

\section{R: Retailer)}

\begin{tabular}{|c|c|c|c|c|c|}
\hline \multirow{2}{*}{\begin{tabular}{|l|}
$\begin{array}{l}\text { Institutional } \\
\text { pressures }\end{array}$ \\
Coercive
\end{tabular}} & \multicolumn{2}{|c|}{ Sustainability Practice } & \multirow{2}{*}{$\begin{array}{l}\text { FSC stage } \\
\text { Grower/Breeder }\end{array}$} & \multirow{2}{*}{$\begin{array}{l}\text { Performance } \\
\text { Quality }\end{array}$} & \multirow[t]{2}{*}{ Reputation } \\
\hline & Environmental & $\mathrm{NRC}$ & & & \\
\hline & Social & $\mathrm{H} \& \mathrm{~S}$ & Grower/Breeder & Quality & \\
\hline & Social & $\mathrm{H} \& \mathrm{~S}$ & Processor & Quality & \\
\hline & Social & $\mathrm{H} \& \mathrm{~S}$ & Distributor & Quality & \\
\hline & Social & $\mathrm{H} \& \mathrm{~S}$ & Retailer & Quality & \\
\hline \multirow[t]{19}{*}{ Normative } & Environmental & NRC & Grower/Breeder & Quality & Env. Rep \\
\hline & Environmental & GPPT & Processor & Efficiency & Env. Rep \\
\hline & Environmental & GPPT & Distributor & Efficiency & \\
\hline & Environmental & GPPT & Distributor & Flexibility & \\
\hline & Environmental & GPPT & Retailer & Efficiency & Env. Rep \\
\hline & Social & Community & Processor & Efficiency & Social Rep \\
\hline & Social & Community & Distributor & Efficiency & Social Rep \\
\hline & Social & Community & Retailer & & Social Rep \\
\hline & Social & $\mathrm{H} \& \mathrm{~S}$ & Grower/Breeder & Quality & \\
\hline & Social & $\mathrm{H} \& \mathrm{~S}$ & Processor & Quality & \\
\hline & Social & W\&HR & Grower/Breeder & & Social Rep \\
\hline & Social & W\&HR & Processor & & Social Rep \\
\hline & Social & W\&HR & Distributor & & Social Rep \\
\hline & Social & W\&HR & Retailer & & Social Rep \\
\hline & Economic & $\mathrm{SS}$ & Grower/Breeder & & Env. Rep \\
\hline & Economic & $\mathrm{SS}$ & Processor & & Social Rep \\
\hline & Economic & $\mathrm{SS}$ & Retailer & & Social Rep \\
\hline & Economic & $\begin{array}{l}\text { Support SC } \\
\text { partners }\end{array}$ & Processor & & Social Rep \\
\hline & Economic & $\begin{array}{l}\text { Support SC } \\
\text { partners }\end{array}$ & Retailer & & Social Rep \\
\hline \multirow[t]{4}{*}{ Mimetic } & Environmental & NRC & Grower/Breeder & Quality & Env. Rep \\
\hline & Environmental & GPPT & Processor & Efficiency & \\
\hline & Environmental & GPPT & Distributor & Efficiency & \\
\hline & Environmental & GPPT & Retailer & Efficiency & \\
\hline
\end{tabular}


Author's version of the article: León-Bravo, V., Caniato, F., \& Caridi, M. (2019). Sustainability in multiple stages of the food supply chain in Italy: practices, performance and reputation. Published in Operations Management Research, 1-22.

https://doi.org/10.1007/s12063-018-0136-9

\section{Appendix A: Interview protocol}

\section{Company General Description}

Interviewees are asked to briefly describe the company in terms of business strategy (e.g., values, quality policy, and service policy), number of facilities, location, product portfolio, market segmentation.

Following, questions are formulated regarding the company supply chain:

- Suppliers: Number and location, type of agreements and-or contracts (long term, short term, minimum volumes, delivery time frame and so on), purchasing management

- Customers: Distribution channels (local, regional, international); Customer relationship: agreements and-or contracts, after sales services.

- Operations: Which operations are performed internally: breeding livestock or agriculture, primary processing (production starting from the raw materials), secondary processing (processing from semi-finished), packaging, transport and distribution, retailing

\section{Sustainability approach:}

Interviewees are asked to describe the company's strategy for sustainability, when it started and how it evolved (objectives and organizational structure, if existing). In addition, the most important reasons behind the choices related to the strategy for sustainability (regulatory compliance, cost reduction, image, and competitive advantage).

Moreover, the most important obstacles/ challenges encountered (high costs and resource consuming, lack of expertise/training, lack of commitment, metrics, suppliers / customers).

Specifically, which are the activities/programs/initiatives implemented in the following areas:

- Environmental responsibility:

○ Environmental regulations to comply to. If there is no particular regulation: internal environment respecting policy (e.g., energy saving, water wasting, recycling material, renewable energy)

○ Waste management: type of waste, discard, reuse, donation

○ Supplier's sustainability: if regulations /policies exist, how is it ensured that they are respected. If it exists, what is the environmental criteria for selecting and evaluating suppliers. If it exists, what are the practices performed together with suppliers and why.

○ Others 
Author's version of the article: León-Bravo, V., Caniato, F., \& Caridi, M. (2019). Sustainability in multiple stages of the food supply chain in Italy: practices, performance and reputation. Published in Operations Management Research, 1-22.

https://doi.org/10.1007/s12063-018-0136-9

- Social involvement and community responsibility:

O Internal practices for employees' wellbeing: Training programs for self-safety, for product handling, for product knowledge (e.g., nutrition, importance for the company, etc.). Career programs. Employee's family involvement

○ For costumers and community: If it exists, how the sustainability strategy is communicated to consumers (e.g., origin, nutrition facts, fair trade, carbon footprint, recipes). Programs implemented for consumer education, for community development

○ Others

\section{Performance and Reputation}

Interviewees are asked to describe if there are any measurement, reporting and-or communication tools to evaluate the sustainability practices implemented. Questions are formulated regarding:

- What practices are related to the company's performance in terms of quality, efficiency, responsiveness and flexibility

- Formal and-or informal mechanisms for sharing the sustainability objectives and results internally, and externally:

○ Tools and-or measures used to monitor the company's performance in terms of sustainability? (e.g., KPIs, results monitoring, publicity, employee training. Access to suppliers' /customers' results

- Practices in the upstream and downstream stages that are relevant for the company's operations and performance

○ How are they monitored, communicated and-or evaluated?

○ Do customers encourage/ask to develop/ improve any sustainability related practice?

- What kind and how often information is required

- If the objectives mentioned in the sustainability approach section are related to company's image or competitive advantage:

○ What practices are related to the company's sustainability image/reputation

○ How are the relevant practices monitored/ communicated and-or evaluated (if they are)

- Practices in the upstream and downstream stages that are relevant for the company's sustainability image/ reputation

- Others 
Appendix B: Sustainability practices implemented in the cases under study

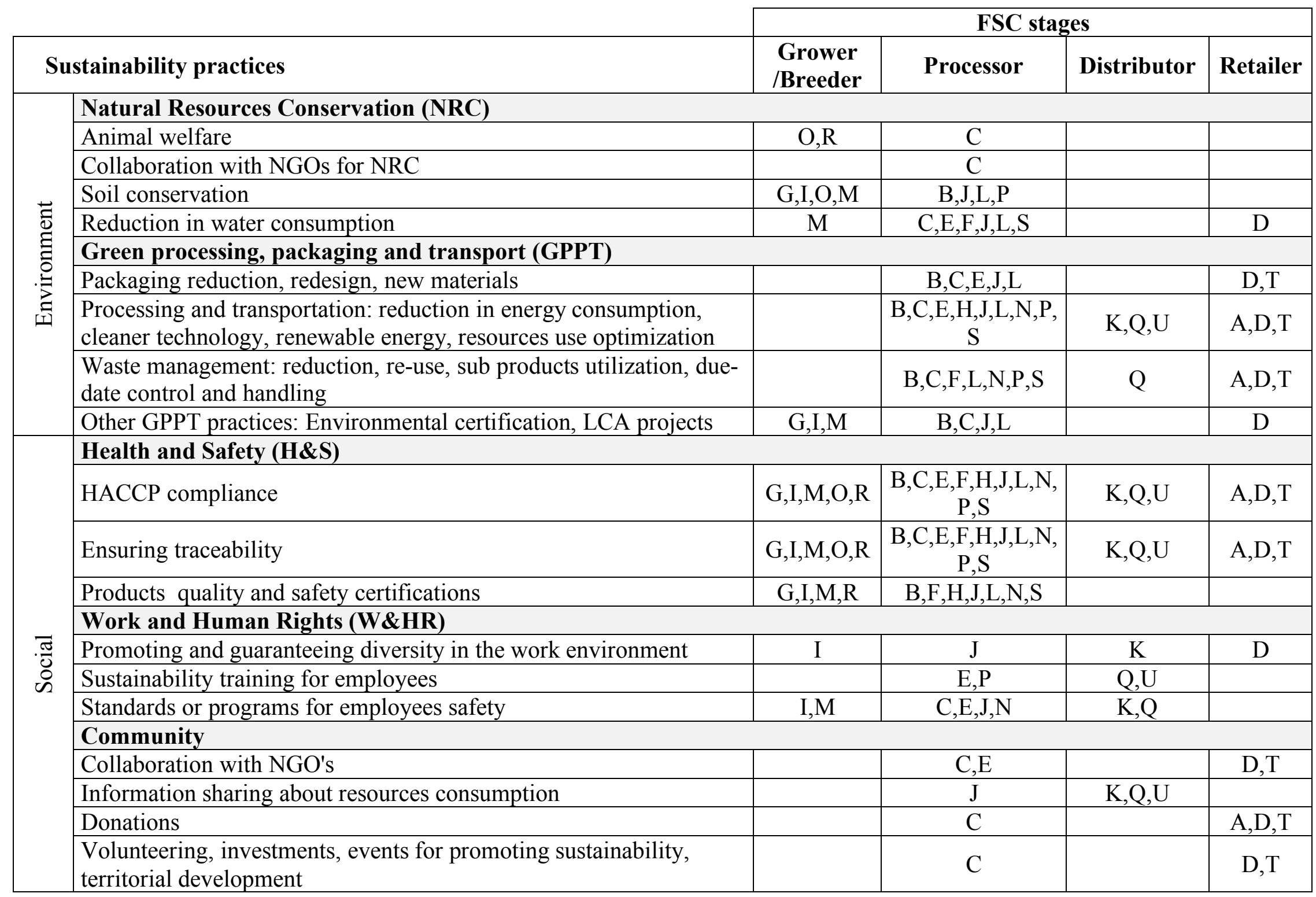




\begin{tabular}{|c|c|c|c|c|c|}
\hline & Consumer education about healthier habits & & $\mathrm{C}, \mathrm{E}, \mathrm{J}, \mathrm{L}, \mathrm{P}$ & & $\mathrm{D}, \mathrm{T}$ \\
\hline & Products for specific categories of consumers & & $\mathrm{B}, \mathrm{L}$ & & \\
\hline \multirow{6}{*}{ 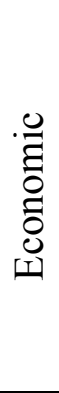 } & \multicolumn{5}{|l|}{ Sustainable Sourcing (SS) } \\
\hline & $\begin{array}{l}\text { Selection, monitoring and control partners/suppliers considering } \\
\text { environmental and social factors }\end{array}$ & $\mathrm{M}, \mathrm{O}$ & $\mathrm{C}, \mathrm{E}, \mathrm{F}, \mathrm{H}, \mathrm{J}, \mathrm{L}$ & $\mathrm{Q}, \mathrm{U}$ & $\mathrm{D}, \mathrm{T}$ \\
\hline & Sustainable procurement practices & & $\mathrm{B}, \mathrm{C}, \mathrm{L}$ & & \\
\hline & \multicolumn{5}{|l|}{ Support SC partners } \\
\hline & Facilitate and/or spread know-how & & $\mathrm{B}, \mathrm{C}$ & & \\
\hline & $\begin{array}{l}\text { Investment/ fostering financial assistance / joint strategies for } \\
\text { economic development }\end{array}$ & & B & & $\mathrm{D}, \mathrm{T}$ \\
\hline
\end{tabular}

